\title{
MEDICAL SPA VERSUS HEALTH TOURISM
}

\author{
[Tradičné kúpel'níctvo verzus zdravotný cestovný ruch] \\ Marian Gúčik ${ }^{1}$, Diana Kvasnová ${ }^{2}$, Kristína Pančíková $^{3}$ \\ ${ }^{1}$ Univerzita Mateja Bela, Ekonomická fakulta, Tajovského 10, 97590 Banská Bystrica \\ Email:marian.gucik@umb.sk \\ ${ }^{2}$ Univerzita Mateja Bela, Ekonomická fakulta, Tajovského 10, 97590 Banská Bystrica \\ Email:diana.kvasnova@umb.sk \\ ${ }^{2}$ Univerzita Mateja Bela, Ekonomická fakulta, Tajovského 10, 97590 Banská Bystrica \\ Email:kristina.pancikova@umb.sk
}

\begin{abstract}
The current fast lifestyle, workload and stress negatively affect the national health. The growth of health awareness is reflected in requirements of the spa products. The aim of the article is to show the relationship of traditional spas and health tourism and explore present trends in meeting demand for services of Slovak Health Spa. Analysis of selected spa offer indicates the transition from the traditional products of medical treatment to the products of wellness, fitness, beauty with typically shorter duration for specific target groups of guests.
\end{abstract}

Key words: Health Tourism, Medical Spa, Spa Products, Wellness.

JEL classification: L83

Doručeno redakci: 4.5.2016; Recenzováno: 10.5.2016; 30.5.2016; Schváleno k publikování: 24.8.2016

\section{Úvod}

Kúpel'níctvo má mnohoročnú tradíciu a predpokladá existenciu prírodných liečivých zdrojov zeme, vody a klímy (prírodná liečivá voda, prírodné liečivé peloidy, prírodné liečivé plyny a liečivá klíma). Terapeutická hodnota termálnej vody a klímy bola známa už v antickom Grécku a Ríme, ktorých obyvatelia trávili vel’a času v početných kúpel’ných miestach za liečebným účelom i pre zábavu. Kúpel'né miesta získali svoju popularitu v 14. a 15. storočí, kedy sa spomínajú dodnes slávne kúpele ako Badgastein, Karlovy Vary a i. Pokrok klinickej medicíny za posledných sto rokov odsunul terapeutické metódy založené na empírii a využití prírodných liečivých zdrojov na druhé miesto. Až v 20. storočí sa medicínsky výskum vrátil k definovaniu účinnosti prírodných liečivých zdrojov.

Súčasné kúpel'níctvo na Slovensku patrí do rezortu zdravotníctva a zároveň poskytuje výkony, ktoré pokladáme za súčast' cestovného ruchu. Z hl'adiska zdravotníctva ide o poskytovanie kúpel'nej starostlivosti ako súčasti zdravotnej starostlivosti úplne alebo čiastočne hradenej zo zdravotného poistenia poistencov, ako aj o hospodársku činnost', ktorá zhodnocuje prírodné zdroje a svoje služby ich predajom na trhovom princípe kúpel’ným host'om, ktorí si kúpel'né služby hradia z vlastných príjmov (osobných dôchodkov). Liečebné kúpele na Slovensku využívajú prírodné liečivé zdroje v kombinácii s medikamentóznou liečbou a liečebnou výživou v kúpel’nom prostredí.

\section{Ciel' a materiál}

Ciel'om state je poukázat' na vzt'ah tradičného kúpel'níctva a zdravotného cestovného ruchu a preskúmat' súčasné prejavy $\mathrm{v}$ uspokojovaní dopytu kúpel'ných hostí po službách slovenských liečebných kúpel'ov. Teoretické východiská skúmania spracúvame na základe literárnych zdrojov domácich a zahraničných autorov (Attl, 2005; DSF, 1985; Eliašová, 2012, 
2015; Gúčik, 1995, 2015; IUOTO, 1973; Kučerová, 2013; Orieška, 2011; Marčeková, 2013, 2015; Palenčíková, 2015; Vavrečková, Vaníček, 2014; Zálešáková, 2007, 2015), ktorí sa v rôznej miere zaoberajú kúpel'níctvom a zdravotným cestovným ruchom.

Údaje nevyhnutné na skúmanie uspokojeného dopytu kúpel’ných hostí po službách liečebných kúpel'ov na Slovensku skúmame na vzorke 10 vybraných liečebných kúpel'ov (Bardejovské Kúpele, Bojnice, Dudince, Lúčky, Nimnica, Piešt’any, Rajecké Teplice, Smrdáky, Trenčianske Teplice, Turčianske Teplice) s najvyššími tržbami v roku 2014, a to z hl'adiska vývoja kapacít, štruktúry domácich a zahraničných hostí, počtu prenocovaní, priemernej dížky pobytu a ponúkaných produktov. Štatistické údaje sme získali zo Štatistického úradu SR, Národného centra zdravotníckych informácií a Trend top v cestovaní, ktoré sme analyzovali pomocou vybraných metód opisnej štatistiky a spracovali do tabuliek.

\section{Teoretické východiská skúmanej problematiky}

V posledných dvoch dekádach sa vplyvom rastúceho zdravotného uvedomenia obyvatel'stva stáva silným motívom účasti na cestovnom ruchu aktívne ovplyvňovanie zdravia. Na zdravotný stav človeka pôsobí životné, najmä pracovné a obytné prostredie, výživa, stav telesnej a duševnej hygieny, choroby, stav vyčerpanosti a duševnej pohody (či nepohody) ap. Človek má šancu žit' dlhšie aj zdravšie vtedy, ak si uvedomí nástrahy všedného dňa, ktoré ohrozujú zdroje jeho zdravia. Pod t’archou týchto skutočností patrí u značnej časti obyvatel'stva zachovanie zdravia $\mathrm{k}$ ich ciel'ovým hodnotám. Toto uvedomenie sa prenáša aj do požiadaviek na kúpel'nú liečbu a vol'ný čas.

Tento trend má rastúcu tendenciu nielen u starších, ale aj mladých l'udí a spája sa s pojmom zdravotnej dovolenky, ktorá sa stáva alternatívou vo vol’nom čase a počas dovolenky. Prejavuje sa to aj v nárokoch na ponuku s tým spojených služieb. Na Slovensku sa presadzuje tento trend aj vplyvom rastúcej vrstvy manažérov, ktorí požadujú krátkodobé, ale intenzívne zotavenie. Zdravotný stav a psychickú pohodu treba vidiet' cez psychohygienu, relaxačné techniky, rehabilitačné cvičenia, autorelaxáciu ap.

Zdravotná dovolenka je aktívna forma trávenia vol’ného času, ktorú si volí sám dovolenkár na základe vlastného rozhodnutia. Motiváciu dovolenkára ovplyvňujú najmä zdravotné poškodenia alebo prevencia pred budúcimi, ako aj miera jeho zdravotného uvedomenia. Dovolenkár hl'adá také individuálne ponuky zodpovedajúce jeho osobným potrebám, aby sa necítil príliš viazaný a zároveň, aby uspokojil svoje zdravotné potreby. Predstavy l’udí o zdravotnej dovolenke sa spájajú s tichom, oddychom, zdravým stravovaním, robením niečoho pre zdravie, prechádzkami, zotavením, masážami, kúpel’nou liečbou a to aj s lekárskym dohl'adom (DSF, 1985, s. 8-9). Zdravotná dovolenka sa spája so zdravotným cestovným ruchom. 
Pojem zdravotný cestovný ruch sa na pôde Medzinárodnej únie oficiálnych organizácií cestovného ruchu IUOTO (predchodkyňa UNWTO) objavuje už v roku 1973 ${ }^{1}$. V domácej literatúre sa tento pojem objavuje až v 90. rokoch 20. storočia (Gúčik, 1995). V súčasnosti rozvoj zdravotného cestovného ruchu ovplyvňuje najmä starnutie populácie v Európe i vo svete (Zálešáková, 2007) a následná verejná podpora preventívnych programov a programov na zlepšenie kvality života vo vyššom veku. Starnutie populácie je spojené s predlžujúcou sa strednou dížkou života. Podl'a WHO (Sedláková, 2012) je aktívne starnutie proces optimalizácie príležitostí pre zdravie, participáciu a bezpečnost' za účelom zvýšenia kvality života $v$ jednotlivých vekových etapách. Na Slovensku bol vypracovaný projekt Stratégia aktívneho starnutia a v nadväznosti na to prijatý Národný program aktívneho starnutia na roky 2014 - 2020 (2013). Narastajúcim faktorom je aj nezdravý životný štýl, stres najmä pracujúcich osôb a rastúcej vrstvy manažérov, nedostatok pohybu, nesprávne uspokojovanie výživových potrieb, rast civilizačných chorôb. Tu je priestor pre rozvoj zdravotného cestovného ruchu.

Ponuka zdravotného cestovného ruchu má uspokojovat' potreby a želania hostí v oblasti zdravia s ciel'om regenerovat' sily na každý deň, zachovat' zdravie, objavit' pocity vlastného tela, mat' čas na hru a povinnost', získat' zážitky z dovolenky bez zhonu, mat' pocit slobody, upevnit', resp. obnovit' psychickú a fyzickú rovnováhu. Ide o pohodu, starostlivost' o telo a krásu (wellness, fitness, beauty). Podnikatelia v cestovnom ruchu reagujú na tieto požiadavky ponukou špecifických produktov pre zdravie spojených s odbornou starostlivost'ou a rehabilitáciou. Základom produktu sú pritom športovo-rekreačné aktivity a programy s ciel'om zvýšenia pohybovej aktivity, podnety pre duševnú činnost', ponuka zdravej stravy a telesnej krásy pre pocit radosti zo života.

Názory autorov na klasifikáciu zdravotného cestovného ruchu sa vel'mi rôznia (Attl, 2005; Gúčik, 2015). Najčastejšie sa zhodujú v tom, že zdravotný cestovný ruch (angl. health tourism) zastrešuje: (1) kúpel'ný cestovný ruch (angl. spa tourism), (2) cestovný ruch wellness (angl. wellness tourism) a (3) medicínsky cestovný ruch (angl. medical tourism).

Zdravotný cestovný ruch sa spája s aktívnym využívaním vol'ného času na obnovu fyzických a duševných síl človeka. Produkty zdravotného cestovného ruchu ponúkajú nielen liečebné kúpele, ale aj wellness hotely a d’alšie zariadenia cestovného ruchu v rekreačných strediskách (akvaparky s ponukou wellness služieb, hotely s wellness centrom) (Marčeková, Šebová, Galvánková, 2015).

Liečebné kúpele sa prioritne zameriavajú na kúpel'nú starostlivost' (súčast' zdravotnej starostlivosti), ale vplyvom poklesu financovania kúpel'nej liečby zdravotnými poist'ovňami,

\footnotetext{
${ }^{1}$ Zdravotnému cestovnému ruchu bol venovaný 39. kongres AIEST (Budapešt', 1989) na tému „Od tradičnej kúpel’nej liečby k moderným formám zdravotného cestovného ruchu“, ktorý zdôraznil, že liečebné kúpele by mali okrem kúpel'nej liečby chronických chorôb a kúpel'nej rehabilitácie po akútnych ochorenia a operáciách rozširovat' svoju profylaktickú činnost' zameranú na prevenciu proti rizikovým faktorom a nové formy zdravotného cestovného ruchu.

Pozornost' tejto problematike venoval aj medzinárodný kongres „Európske kúpele - fakty a perspektívy“ (Freudenstadt, 1992), na ktorom sa upozorňovalo na nevyhnutnost' premeny kúpel'ov na profylaktické zariadenia, na vzt’ah kúpel'nej liečby a zdravotného cestovného ruchu. Liečebné kúpele, ktoré majú často mnoho storočnú tradíciu sa musia nevyhnutne prispôsobovat’ potrebám doby.

Zdravotnému cestovnému ruchu ako súčasnému rozvojovému trendu bola venovaná aj medzinárodná vedecká konferencia Turistica Bistriciensis 2015 (Folia Turistica 5. Zborník vedeckých prác. Banská Bystrica: UMB, Ekonomická fakulta).
} 
rozširujú ponuku svojich služieb pre samoplatitel'ov (kúpel'ný cestovný ruch). Súčasný kúpel'ný host' kladie dôraz na kombináciu odbornej lekárskej starostlivosti, kvalitné ubytovacie a stravovacie služby spolu s ponukou kultúrneho a športového vyžitia. J. Zálešáková (2015) zdôrazňuje priority pre zdravotnícke systémy (vrátane kúpel'níctva) z hl'adiska primárnej prevencie, a to podl'a očakávaní jednotlivcov a spoločnosti. L'udia očakávajú nezávislost' v starobe a zlepšenie fyzického a mentálneho zdravia. Spoločnost' očakáva zachovanie pracovnej schopnosti občanov, zníženie výdavkov na zdravotníctvo a v sociálnej oblasti.

Ak v súvislosti s tradičným kúpel'níctvom hovoríme aj o kúpel'nom cestovnom ruchu ide zvyčajne o zdravotno-preventívne a liečebné činnosti pod odborným dohl'adom vo vol'nom čase kúpel'ného host'a. Kúpel'ná starostlivost' sa poskytuje ako ústavná (sanatórna) alebo ambulantná, ak je pokračovaním liečebného procesu počas práceneschopnosti pacienta.

Wellness sa chápe ako harmónia všetkých aspektov života, má za ciel' udržanie a obnovu zdravia a pohodu človeka (Vavrečková, Vaníček, 2014). Pokladá sa za zdravý životný štýl, ktorý je prevenciou proti chorobám. Spája sa s aplikáciou vody na človeka, ale dokonca aj mlieka, čokolády, piva ap. Čoraz viac zariadení ponúka bazény, posilňovne, sauny a masáže, tradičnú indickú medicínu (ajurveda) a tradičnú čínsku medicínu. Nositel’om dopytu je najmä obchodná klientela, ktorá využíva tieto služby ako prevenciu proti stresu, pracovnému vypätiu a únave, vysokému tempu života. Podstatou wellness je teda pozitívna zmena životného štýlu v záujme duševnej, emocionálnej a fyzickej rovnováhy prostredníctvom zdravej výživy, pohybu a ovládania stresu. J. Zálešáková (2015) poukazuje na odlišnost' produktov liečebných kúpel'ov a wellness.

Tabul'ka 1: Požiadavky na liečebné kúpele a wellness

\begin{tabular}{|c|c|}
\hline Liečebné kúpele & Wellness \\
\hline $\begin{array}{l}\text { - licencia na poskytovanie kúpel'nej } \\
\text { starostlivosti (uznanej ako súčast' } \\
\text { zdravotnej starostlivosti) } \\
\text { - } \quad \text { využívanie uznaného prírodného } \\
\text { liečivého zdroja v liečbe } \\
\text { - } \quad \text { silné medicínske zázemie } \\
\text { (zdravotnícky personál) } \\
\text { - implementácia nových liečebných a } \\
\text { vyšetrovacích metód na báze } \\
\text { vedeckého poznania } \\
\text { - liečebné, rehabilitačné a preventívne } \\
\text { pobyty } \\
\text { - dížka pobytu minimálne } 14 \text { dní }\end{array}$ & $\begin{array}{l}\text { - wellbeing (stav zdravia a pohody) a } \\
\text { fitness (fyzická kondícia) } \\
\text { - zážitkové procedúry, ktoré nie sú uznané } \\
\text { ako liečebné } \\
\text { - } \quad \text { služby zamerané na kondíciu, krásu a } \\
\text { relax } \\
\text { - ponuka nevyžaduje prítomnost' lekára a } \\
\text { špecializovaných zdravotníckych } \\
\text { pracovníkov } \\
\text { - dížka pobytu 3-7 dní }\end{array}$ \\
\hline
\end{tabular}

Zdroj: Zálešáková (2015)

Wellness zostane významným faktorom cestovného ruchu aj v najbližších desat'ročiach. Ak sa liečebné kúpele rozhodnú pre uspokojovanie tohto dopytu, musí sa wellness stat' súčast'ou ich špecifickej ponuky ako medical wellness. Neexistuje žiadny štandardný vzor ponuky tradičného kúpel'níctva a medical wellness. Treba však pamätat' na to, že ponuka služieb medical wellness zahŕňa rad nových služieb, ktoré nie sú typické pre liečebné kúpele.

Medicínsky cestovný ruch predstavuje koncepciu cestovania za účelom využitia zdravotníckych, klinických služieb alebo podstúpenia operácie najmä v zahraničí a získania 
doma nedostupných služieb, resp. vyššej hodnoty. Okrem medicínskych služieb, ktoré vyžadujú starostlivost' kvalifikovaných špecialistov (napr. kozmetická a plastická chirurgia, liečba neplodnosti, stomatológia, kardiochirurgia, ortopedická chirurgia, očná chirurgia ap.) očakávajú hostia ponuku služieb cestovného ruchu. V liečebných kúpel’och na Slovensku hostia z Nemecka a Rakúska svoj pobyt spájajú najčastejšie so stomatologickým ošetrením (Palenčíková, 2015).

\section{Dosiahnuté výsledky a diskusia}

V roku 2015 malo na Slovensku štatút liečebných kúpel'ov 21 miest a 9 kúpel'ných liečební. Prírodné liečebné kúpele a kúpel'né liečebne sa v zmysle Kúpel'ného zákona č. 577/2004 Z. z. pokladajú za zariadenia ústavnej zdravotnej starostlivosti. V tomto roku už neboli v prevádzke liečebné kúpele Korytnica, Lučivná, Štrbské Pleso a Tatranské Matliare (kúpel’né zariadenie sa prest'ahovalo do Tatranských Zrubov). Svoju činnost' revitalizovali liečebné kúpele Červený Kláštor (Smerdžonka) a potenciál majú aj d’alšie v minulosti aktívne liečebné kúpele (Eliašová, 2015).

Silnou stránkou slovenského kúpel’níctva je (Zálešáková, 2015): (1) že je súčast' zdravotnej starostlivosti s ponukou služieb zdravotného cestovného ruchu, (2) existencia lokálnych prírodných liečivých zdrojov (prírodné liečivé vody, klimatické podmienky vhodné na liečenie), (3) silné medicínske zázemie (uznané liečebné postupy, kvalifikovaný zdravotnícky personál, primerané technické vybavenie) a schválené indikačné zameranie v závislosti od prírodného liečivého zdroja, (4) špecifické chránené prírodné prostredie. Vznik nových kúpel'ných zariadení je viazaný na výskyt prírodného liečivého zdroja alebo vhodné klimatické podmienky. Musia sa pritom preukázat' liečivé účinky zdroja a splnit' legislatívne podmienky uvedené $\mathrm{v}$ Kúpel'nom zákone, spĺnat' aj minimálne materiálno-technické a personálne vybavenie. Výkony liečebných kúpel'ov na Slovensku sa za takmer štvrt'storočie významne zmenili (tabul'ka 2).

Tabul'ka 2: Vývoj výkonov slovenských liečebných kúpel’ov v rokoch 1990 - 2014

\begin{tabular}{|l|c|c|c|c|}
\hline Ukazovatel'/Rok & 1990 & 2000 & 2010 & 2014 \\
\hline Počet lôžok & 11171 & 12819 & 12021 & 12888 \\
Využitie lôžok v \% & $\cdot$ & $\cdot$ & 63,0 & 62,4 \\
Počet kúpel'ných hostí & 150235 & 135123 & 259506 & 299032 \\
Počet prenocovaní & 3712974 & 3097780 & 2569109 & 2617209 \\
z toho zahraničných hostí (v \%) & 10,33 & 24,9 & 21,7 & 30,00 \\
Priemerná dĺžka pobytu (v dňoch) & 24,7 & 22,9 & 9,9 & 8,8 \\
Počet priamych pracovných miest & $\cdot$ & 6314 & $\cdot$ & 4500 \\
Počet liečebných kúpel'ov & & & & \\
a kúpel'ných liečební & 23 & 24 & 31 & 30 \\
\hline
\end{tabular}

Pozn: . nezistený údaj

Zdroj: Ústav zdravotníckej informatiky a štatistiky (2002); ŠÚSR (2011, 2015)

V rokoch 1990 až 2014 vzrástol počet lôžok v liečebných kúpel'och o 15,3 \%. Kým počet kúpel'ných hostí (hostia vyslaní zdravotnou poist'ovňou a samoplatitelia) vzrástol takmer dvojnásobne, počet ich prenocovaní poklesol o $29,5 \%$, čo sa prejavilo v poklese priemernej dížky pobytu z 24,7 dní na 8,8 dňa. Využitie lôžok v liečebných kúpel'och je dvojnásobne vyššie $(62,4 \%)$ ako v cestovnom ruchu. Z 299032 kúpel'ných hostí tvorili domáci 77,0 \%. Zahraniční hostia prichádzali najčastejšie z Nemecka, Česka, Izraela, Ruska a Rakúska. Viac ako polovica kúpel'ných hostí (56,3 \%) navštevuje desat' liečebných kúpel'ov (Piešt'any, 
Turčianske Teplice, Bardejovské kúpele, Trenčianske Teplice, Bojnice, Dudince, Rajecké Teplice, Lúčky, Nimnica, Smrdáky), ktoré dosahujú aj najvyššie tržby (tabul'ka 3).

Tabul'ka 3: Tržby a návštevnost' vybraných liečebných kúpel’ov v roku 2014

\begin{tabular}{|l|c|c|c|c|c|}
\hline Kúpele/Výkony & Tržby (EUR) & Tržby (\%) & Počet hostí & $\begin{array}{c}\text { Domáci } \\
\text { hostia (\%) }\end{array}$ & $\begin{array}{c}\text { Zahraniční } \\
\text { hostia (\%) }\end{array}$ \\
\hline SLK Piešt'any & 29437712 & 29,5 & 41736 & 37,5 & 62,5 \\
SLK Turčianske Teplice & 11536572 & 11,6 & 21861 & 82,7 & 17,3 \\
Bardejovské Kúpele & 11503825 & 11,5 & 22246 & 91,5 & 8,5 \\
Kúpele Trenčianske Teplice & 11380263 & 11,4 & 18396 & 81,1 & 18,9 \\
Kúpele Bojnice & 9449155 & 9,5 & 24163 & 82,9 & 17,1 \\
Kúpele Dudince & 7232714 & 7,3 & 11970 & 84,1 & 15,9 \\
SLK Rajecké Teplice & 6300000 & 6,3 & &. &. \\
Kúpele Lúčky & 5088619 & 5,1 & 12150 & 82,8 & 17,2 \\
Kúpele Nimnica & 4396715 & 4,4 & 11777 & 85,7 & 14,3 \\
Kúpele Smrdáky & 3417717 & 3,4 & 4032 & 86,3 & 13,7 \\
\hline Spolu & 99743292 & 100,0 & 168331 & 72,9 & 27,1 \\
\hline
\end{tabular}

Pozn: . nezistený údaj

Zdroj: spracované podl'a Trend top v cestovaní (2010 až 2015)

Dopyt po kúpel'ných službách je relatívne stabilný a negatívne ho neovplyvnila ani hospodárska recesia v prvej dekáde 21. storočia. Liečebné kúpele sa dlhodobo podiel'ajú približne $20 \%$ na tržbách za ubytovanie v cestovnom ruchu (SACR, 2015). Tržby desiatich kúpel'ných podnikov s najvyššími tržbami v roku 2014 dosiahli takmer 100 mil. EUR. Z toho asi tretina tržieb pripadá na Slovenské liečebné kúpele Piešt’any, ktoré patria medzi najviac navštevované kúpel'né miesta na Slovensku. Návštevníci vybraných kúpel'ných podnikov sa 1 v roku 2014 podiel'ali 56,3 \% na návštevnosti všetkých liečebných kúpel’ov na Slovensku. V štruktúre návštevnosti dominovali hostia zo zahraničia (62,5\%). Ide o extrém, ktorý nie je charakteristický pre vybranú vzorku liečebných kúpel'ov s najvyššími tržbami ani všeobecne pre slovenské liečebné kúpele.

Najčastejšie sa v slovenských liečebných kúpel'och v roku 2013 liečili choroby dospelej populácie (Štatistické prehl'ady 2014, č. 2) choroby pohybového ústrojenstva (66\%), respiračné choroby $(9 \%)$, choroby tráviaceho ústrojenstva $(8 \%)$, kardiovaskulárne choroby (7\%), kožné choroby (3\%), ženské choroby $(2,5 \%)$, neurologické choroby $(2 \%)$, stavy po onkologickej liečbe $(1,5 \%)$. Z celkového počtu liečebných pobytov domácich hostí poist'ovne uhradili $53,1 \%$ pobytov a $46,9 \%$ boli samoplatitelia.

Pre samoplatitel'ov je rozhodujúcim kritériom pri výbere liečebných kúpel'ov okrem indikácií aj ponuka kúpel'ných služieb. Dnešní hostia preferujú multiopcionálnu ponuku služieb, t. j. takú, ktorá im poskytuje čo najviac možností na uspokojenie ich rôznorodých potrieb (Gúčik a kol., 2010). K dôležitým interným faktorom rozhodovania samoplatitel'ov patrí indikačné zameranie, dížka a cena pobytov, liečebné procedúry a ponuka doplnkových služieb. Z externých faktorov ich rozhodovanie ovplyvňuje lokalizácia a infraštruktúrna vybavenost' kúpel'ného miesta. Kým vo väčších liečebných kúpel'och tvoria samoplatitelia v priemere asi polovicu domácich hostí, v menších kúpel'och je ich podiel nižší (tabul'ka 4). 
Tabul'ka 4: Domáci samoplatitelia vo vybraných liečebných kúpel’och v rokoch $2009-2014$ v \%

\begin{tabular}{|l|c|c|c|c|c|c|c|}
\hline Liečebné kúpele/Rok & 2009 & 2010 & 2011 & 2012 & 2013 & 2014 & $\begin{array}{c}\text { Priemer } \\
2009-2014\end{array}$ \\
\hline SLK Piešt’any & 49,0 & 48,2 & $\cdot$ & $\cdot$ & $\cdot$ & $\cdot$ & 48,6 \\
SLK Turčianske Teplice & 45,0 & 47,0 & 56,6 & 57,6 & 48,7 & 55,1 & 51,7 \\
Bardejovské Kúpele & 47,2 & 50,0 & 38,0 & 56,8 & 59,0 & 62,6 & 52,2 \\
Kúpele Trenčianske Teplice & 58,5 & 59,0 & 67,0 & 68,7 & 67,4 & 66,6 & 64,5 \\
Kúpele Bojnice & 61,5 & 51,6 & 54,5 & 51,7 & 56,1 & 55,8 & 55,2 \\
Kúpele Dudince & 61,0 & 49,0 & 34,5 & 51,0 & 40,1 & 55,6 & 48,5 \\
SLK Rajecké Teplice & 90,7 & $\cdot$ & $\cdot$ & $\cdot$ & $\cdot$ & $\cdot$ & 90,7 \\
Kúpele Lúčky & 36,2 & 13,1 & 16,0 & 18,4 & 19,3 & 20,6 & 20,6 \\
Kúpele Nimnica & 38,0 & 33,0 & 32,0 & 33,0 & 32,0 & 21,0 & 31,5 \\
\hline
\end{tabular}

Pozn: . - nezistený údaj

Zdroj: spracované podl'a Trend top v cestovaní, 2010 až 2015.

S ciel'om oslovit' čo najviac hostí a obstát' v rastúcej konkurencii liečebné kúpele svoju ponuku služieb diverzifikujú. Početnou a pestrou ponukou sa chcú odlíšit' nielen od iných liečebných kúpel'ov, ale aj od konkurencie, ktorú pre nich predstavujú najmä termálne kúpaliská. Čoraz častejšie preto ponúkajú pobyty, ktoré majú skôr preventívny charakter. Tieto pobyty súvisia hlavne s regeneráciou fyzických a psychických síl, obyčajne však host'om umožňujú v prípade záujmu konzultovat' ich zdravotný stav s lekárom. Napriek tomu, že zo 139 ponúkaných kúpel'ných pobytov (produktov) na webových stránkach vybraných liečebných kúpel'ov s najvyššími tržbami v roku 2014, majú početnejšie zastúpenie pobyty s povinným lekárskym vyšetrením, významný je aj podiel pobytov, ktoré ho neobsahujú (tabul'ka 5).

Tabul'ka 5: Štruktúra pobytov vo vybraných liečebných kúpel'och podl’a rozsahu lekárskej starostlivosti

\begin{tabular}{|l|c|c|}
\hline Rozsah lekárskej starostlivosti/Pobyty & Počet pobytov & Podiel pobytov (\%) \\
\hline S povinným lekárskym vyšetrením & 78 & 56,1 \\
Bez povinného lekárskeho vyšetrenia & 61 & 43,9 \\
\hline Spolu & 139 & 100,0 \\
\hline
\end{tabular}

Zdroj: spracované podl'a ponuky pobytov na webových stránkach vybraných kúpel’ov k 23. 1. 2016

Štruktúra pobytov vo vybraných liečebných kúpel'och naznačuje, že na kúpel’nú liečebnú starostlivost' pripadá cca $42 \%$ pobytov, pritom do popredia sa dostávajú pobyty zamerané na pohodu, starostlivost' o telo a krásu, tzv. wellness, fitness a beauty. Na konci 20. storočia začali v dôsledku zavádzania tohto trendu liečebné kúpele transformovat' svoju ponuku. Ich produkt sa stal komplexnejším a skvalitnili sa základné (zdravotnícke, ubytovacie, stravovacie, kultúrno-spoločenské) aj doplnkové služby (Orieška, 2011). Absolvovanie pobytov wellness, fitness a beauty prispieva k revitalizácii tela aj mysle. Vo vybraných liečebných kúpel'och tvoria tieto pobyty viac ako tretinu ponuky (cca $35 \%$ ). Najčastejšie obsahujú okrem ubytovania a stravovacích služieb rozmanité procedúry, predovšetkým vaňové kúpele, masáže, skrášl'ujúce a omladzujúce procedúry, bahenné zábaly s relaxačnými a zdraviu prospešnými účinkami. Obvykle zahŕňajú aj vstup do bazénov, sáun a posilňovní. V snahe urobit' ponuku atraktívnejšou majú tieto pobyty často svojské názvy, ktoré môžu potenciálnym host'om komplikovat' výber vhodného produktu. Ponuku liečebných kúpel'ov 
doplńajú aj sezónne, redukčné a športovo-rekreačné pobyty (cca $23 \%$ ), ktoré sú typickým produktom wellness hotelov (tabul'ka 6).

Tabul'ka 6: Štruktúra pobytov vo vybraných liečebných kúpel’och podl'a zamerania

\begin{tabular}{|l|c|c|}
\hline Zameranie/Pobyty & Počet pobytov & Podiel pobytov (\%) \\
\hline Liečebná starostlivost' & 58 & 41,7 \\
Wellness, fitness a beauty & 49 & 35,3 \\
Sezóna (Vel'ká noc, Silvester ap.) & 11 & 7,2 \\
Redukcia hmotnosti & 10 & 5,0 \\
Šport a aktívny odpočinok & 7 & 7,9 \\
Iné & 4 & 2,9 \\
\hline Spolu & 139 & 100,0 \\
\hline
\end{tabular}

Zdroj: spracované podl'a ponuky pobytov na webových stránkach vybraných kúpel’ov k 23. 1. 2016

Meniace sa zameranie pobytov sa prejavuje aj v ich dížke. V roku 2014 domáci hostia trávili v liečebných kúpel'och priemerne 10 dní a priemerná dížka pobytu zahraničných hostí bola 9 dní (SACR, 2015). V minulosti sa v liečebných kúpel'och odporúčali 21- až 28-dňové pobyty. Táto dížka pobytov je aktuálna aj v súčasnosti, ale vzt'ahuje sa prevažne na pobyty kúpel'nej starostlivosti čiastočne alebo úplne hradené zdravotnými poist’ovňami. Na vybranej vzorke liečebných kúpel'ov môžeme pozorovat', že podiel 21-dňových pobytov tvorí len malú čast' ich ponuky $(3,6 \%)$ a dížka väčšiny ponúkaných pobytov je podstatne kratšia. Takmer polovica $(48,9 \%)$ pobytov netrvá dlhšie ako sedem dní. V ponuke sa vyskytujú aj víkendové pobyty $(15,8 \%)$, ktorými liečebné kúpele reagujú na aktuálne trendy hostí cestovat' viackrát do roka na kratšie obdobie. Niektoré pobyty liečebné kúpele časovo neobmedzujú, ale hostia môžu dížku trvania prispôsobit' vlastným potrebám (tabul'ka 7).

Tabul'ka 7: Štruktúra dížky pobytov vo vybraných liečebných kúpel’och

\begin{tabular}{|l|c|c|c|c|c|c|c|}
\hline $\begin{array}{l}\text { Pobyty/ } \\
\text { Počet prenocovaní }\end{array}$ & 1 až 2 & 3 až 6 & 7 až 12 & $\begin{array}{c}13 \text { až } \\
20\end{array}$ & $\begin{array}{c}21 \text { a } \\
\text { viac }\end{array}$ & Neobmedzený & Spolu \\
\hline $\begin{array}{l}\text { Počet pobytov } \\
\text { Podiel pobytov }(\%)\end{array}$ & 22 & 68 & 27 & 5 & 5 & 12 & 139 \\
\hline
\end{tabular}

Pozn.: Údaje v tabul'ke sú orientačné. Dĺžka pobytov sa obvykle prispôsobuje požiadavkám hostí.

Zdroj: spracované podl'a ponuky pobytov na webových stránkach vybraných kúpel'ov k 23. 1. 2016

Okrem kratších pobytov a trendu wellness, fitness a beauty sa v liečebných kúpel'och špecializuje ponuka na konkrétne ciel'ové skupiny hostí. Tieto pobyty tvoria viac ako štvrtinu všetkých pobytov vybraných liečebných kúpel'ov a orientujú sa hlavne na seniorov, ženy a páry. S ciel'om sprístupnit' pobyty v kúpel'och aj pre sociálne znevýhodnených seniorov spolupracujú niektoré liečebné kúpele s neziskovými organizáciami (napr. Jednotou dôchodcov Slovenska), ktoré získavajú na organizovanie kúpel'ných pobytov pre seniorov dotácie zo štátneho rozpočtu (Hudecová, 2015).

Súčasná ponuka slovenských liečebných kúpel’ov reflektuje zmeny požiadaviek v dopyte. S úmyslom uspokojovat' viaceré ciel'ové skupiny hostí vytvárajú liečebné kúpele rôznorodú a čoraz špecializovanejšiu ponuku (Kučerová, Marčeková, 2013). Komplexnými službami sa snažia posilnit' svoju konkurencieschopnost', a tak zlepšit' svoju pozíciu na trhu zdravotného cestovného ruchu, na ktorý sa v súčasnosti okrem liečebných kúpel'ov dostávajú aj d'alšie subjekty bez štatútu liečebných kúpel'ov. Svoju ponuku a liečivé účinky vody ako marketingový t’ah prezentujú kúpaliská, napr. Komárno (ponúka liečenie reumatických chorôb, organických nervových chorôb podobne ako LK Piešt’any LK Trenčianske Teplice), 
„termálne kúpele“Vel'ký Meder (pohybové ústrojenstvo), „Slovenské mítve more“ Podhájska (pohybové ústrojenstvo, dýchacie cesty, kožné ekzémy, zažívacie ústrojenstvo), termálne kúpalisko Patince (choroby pohybového ústrojenstva), akvapark Galandia svoju vodu označuje za termálnu ap.

\section{Záver}

Zdravotný cestovný ruch pokladáme za jeden z možných spôsobov ovplyvňovania národného zdravia, ktorý budú nad’alej ovplyvňovat' nielen zmeny v demografickom vývoji sprevádzané starnutím populácie, ale aj narastajúci stres ekonomicky činného obyvatel'stva a rast jeho zdravotného uvedomenia. Je preto nevyhnutné, aby liečebné kúpele ako poskytovatelia služieb zdravotného cestovného ruchu venovali pozornost' nielen seniorom, ale aj manažérom a obyvatel'stvu stredného veku, vzhl'adom na ich potreby, preferencie a kúpyschopnost'. Liečebné kúpele na Slovensku sú konfrontované poklesom financovania kúpel'nej starostlivosti prostredníctvom zdravotných poist'ovní a rastom dopytu zdravotného uvedomenia obyvatel'ov, ktorí chcú preventívne ovplyvňovat' svoje zdravie aj ako samoplatitelia a nositelia dopytu po produktoch medical wellness.

V súčasnosti slovenské liečebné kúpele poskytujú: (1) služby kúpel'nej starostlivosti na domácom trhu pre domáce zdravotné poist'ovne, ktoré majú kúpel'nú starostlivost' zahrnutú ako súčast' liečebného procesu. Plne alebo čiastočne sa zo zdravotného poistenia hradí liečba chronických chorôb, postakútna rehabilitácia, ako aj primárna prevencia zameraná na vybudovanie a overenie nových návykov životného štýlu (zdravá výživa, fyzická aktivita, nefajčenie, manažment stresov a pozitívne myslenie ako je prevencia depresie - podpora mentálneho a fyzického zdravia), regenerácia a edukačné programy. Odporúčaná minimálna dížka pobytu je 14 dní, optimálna 21 až 28 dní. Podiel hostí tejto kategórie klesá v dôsledku poklesu nákupu poukazov na kúpel'nú liečbu od liečebných kúpel'ov; (2) služby samoplatitel'om, ktorí častokrát vyžadujú kratšie koncentrované pobyty zamerané na prevenciu. Ide o služby relaxácie a medical wellness, vrátane poznávania krajiny a kultúrnych zážitkov, ktoré sú krátkodobé (víkendové až 7-dňové). Všetky druhy pobytov možno absolvovat' sanatórne alebo ambulantne.

V prípade zahraničných kúpel'ných hostí ide prevažne o seniorov, ktorí trpia viacerými ochoreniami, vyžadujú preto intenzívnu medicínsku starostlivost' a očakávajú zlepšenie svojho zdravotného stavu. V záujme zvýšenia podielu zahraničných kúpel'ných hostí na návštevnosti liečebných kúpel’ov je nevyhnutné pobyty spájat' s variabilnou ponukou nových konkurencieschopných produktov na európskom trhu.

Budúcnost' európskych liečebných kúpel'ov musí rešpektovat' zmenu životného štýlu obyvatel'ov a ponúkat' popri klasickej kúpel'nej liečbe aj produkty zamerané na prevenciu najčastejších civilizačných chorôb a programy na udržanie kvality života v starobe.

\section{Literatúra}

[1] AIEST, 1989. Von der traditionellen Badekur zu modernen Formen des Gesundheitstourismus. Publication der 1'AIEST No. 30. St. Gall: Niderman Verlag. Bez ISBN.

[2] ATTL, P., 2005. K pojetí lázeňství. Czech hospitality and tourism papers, 1(1), 43-67. Praha: VŠHH. ISSN 1801-1535.

[3] Bardejovské kúpele [online]. [vid. 25. januára 2016]. Dostupné z: www.kupele-bj.sk 
[4] DSF, 1985. Urlaub und Gesundheit. Inovationsmöglichkeiten für Heilbäder und Kurorte. Berlin: Deutsches Seminar für Fremdenverkher. Bez ISBN.

[5] ELIAŠOVÁ, D., 2012. Terminológia v oblasti kúpel'níctva. In: Konkurenceschopnost $v$ cestovním ruchu, gatronomii a hotelnictví. Brno: VŠOB, s. 44-48. ISBN 978-80-87300$19-0$.

[6] ELIAŠOVÁ, D., 2015. Potenciál zaniknutých kúpel'ov pre rozvoj cestovného ruchu v Slovenskej republike. In: Cestovní ruch, hotelnictví a gastronomie jako fenomén 21. století. Brno: VŠOH, s. 45-52. ISBN 978-80-87300-61-9.

[7] GÚČIK, M., 1995. Nový trend - dopyt po zdravotnom cestovnom ruchu. In: Cestovný ruch na prelome tisicroči. Zborník 6. medzinárodnej konferencie o cestovnom ruchu. Banská Bystrica: Dom techniky ZSVTS, s. 55-95. ISBN 80-230-0138-8.

[8] GÚČIK, M., 2015. Zdravotný cestovný ruch ako prejav zdravotného uvedomenia obyvatel'stva. In: Folia Turistica 5. Banská Bystrica: Univerzita Mateja Bela, Ekonomická fakulta, s. 54-61. ISBN 978-80-557-0886-7.

[9] GÚČIK, M. a kol., 2010. Manažment cestovného ruchu. Banská Bystrica: DALI-BB. ISBN 978-80-89090-67-9.

[10] GÚČIK, M., ed., 2015. Folia Turistica 5. Zborník vedeckých prác. Banská Bystrica: Univerzita Mateja Bela, Ekonomická fakulta. ISBN 978-80-557-0886-7.

[11] HUDECOVÁ, D., 2015. Na dotovanú dovolenku môžu íst’ penzisti aj tento rok [online]. [vid. 25. januára 2016]. Dostupné z: www.peniaze.pravda.sk

[12] IUOTO, 1973. Health Tourism. Geneva: United Nations Organisation, 1973.

[13] KUČEROVÁ, J. a R. MARČEKOVÁ, 2013. Inovácie vo vybraných kúpel’ných miestach na Slovensku. In: Folia Turistica 3. Banská Bystrica: Univerzita Mateja Bela, Ekonomická fakulta, s. 68-78. ISBN 978-80-8141-040-6.

[14] Kúpele Bojnice [online]. [vid. 25. januára 2016]. Dostupné z: www.kupele-bojnice.sk

[15] Kúpele Dudince [online]. [vid. 25. januára 2016]. Dostupné z: www.kupele dudince.sk

[16] Kúpele Lúčky [online]. [vid. 25. januára 2016]. Dostupné z: www.kupele-lucky.sk

[17] Kúpele Nimnica [online]. [vid. 25. januára 2016]. Dostupné z: www.kupele nimnica.sk

[18] Kúpele Smrdáky [online]. [vid. 25. januára 2016]. Dostupné z: www.smrdaky. danubiushotels.sk

[19] Kúpele Trenčianske Teplice [online]. [vid. 25. januára 2016]. Dostupné z: www.kupeleteplice.sk

[20] MARČEKOVÁ, R., L. ŠEBOVÁ a L. GALVÁNKOVÁ, 2015. Aktívne starnutie populácie ako príležitost' pre rozvoj zdravotného cestovného ruchu na Slovensku. In: Folia Turistica 5. Banská Bystrica: Univerzita Mateja Bela, Ekonomická fakulta, s. 105111. ISBN 978-80-557-0886-7.

[21] Národný program aktívneho starnutia na roky 2014 - 2020. Ministerstvo práce, sociálnych vecí a rodiny SR [online]. [vid. 25. januára 2016]. Dostupné z: www.employment.gov.sk/files/slovensky/ministerstvo/rada-vlady-sr-prava-seniorov/ npas-2014-2020.pdf

[22] ORIEŠKA, J., 2011. Služby v cestovnom ruchu. 2. čast’. Banská Bystrica: DALI-BB. ISBN 978-80-89090-94-5. 
[23] PALENČÍKOVÁ, Z., 2015. Medicínsky cestovný ruch a jeho rozvoj na Slovensku. In: Folia Turistica 5. Banská Bystrica: Univerzita Mateja Bela, Ekonomická fakulta, s. 124129. ISBN 978-80-557-0886-7.

[24] SACR, 2015. Ubytovacia štatistika cestovného ruchu na Slovensku. Kúpel'ný cestovný ruch 2014/2013 [online]. [vid. 25. januára 2016]. Dostupné z: www.sacr.sk

[25] SEDLÁKOVÁ, D., 2012. Aktívne starnutie. Dobré zdravie pridáva roky života [online]. [vid. 25. januára 2016]. Dostupné z: www.vho.sk

[26] Slovenské liečebné kúpele Piešt’any [online]. [vid. 25. januára 2016]. Dostupné z: www.piestany.danubiushotels.sk

[27] Slovenské liečebné kúpele Rajecké Teplice [online]. [vid. 25. januára 2016]. Dostupné z: www.spa.sk

[28] Slovenské liečebné kúpele Turčianske Teplice [online]. [vid. 25. januára 2016]. Dostupné z: www.therme.sk

[29] STADTFELD, F., 1993. Europäische Kurorte. Fakten und Perspektiven. Lümburgerhof: Medien Verlag. ISBN 3-929469-01-4.

[30] Trend top v cestovaní [online]. Špeciálne vydania 2010 - 2014. [vid. 24. januára 2016]. Dostupné z: www.etrend.sk

[31] VAVREČKOVÁ, E. a J. VANÍČEK, 2014. Význam lázeňství a wellness pro současný cestovní ruch v období změn. In: A. HOLEŠINSKÁ, ed. 5. mezinárodní kolokvium o cestovním ruchu [CD]. Brno: Masarykova univerzita, s. 92-113. ISBN 978-80-107585-6.

[32] ZÁLEŠÁKOVÁ, J., 2007. Slovenské kúpel'níctvo má čo ponúknut'. Euroregióny, 5(4), 11-12. ISSN 1336-605X.

[33] ZÁLEŠÁKOVÁ, J., 2015. Produkty liečebných kúpel’ov na európskom trhu. In: Konferencia Turistica Bistriciensis. Banská Bystrica: Univerzita Mateja Bela, Ekonomická fakulta. 